\title{
Sexual Stage Development of Uromyces appendiculatus and Its Potential Use for Disease Resistance Screening of Phaseolus vulgaris
}

\author{
M. S. McMillan, H. F. Schwartz, and K. L. Otto, Department of Bioagricultural Sciences and Pest Management, \\ Colorado State University, Fort Collins 80523-1177
}

\begin{abstract}
McMillan, M. S., Schwartz, H. F., and Otto, K. L. 2003. Sexual stage development of Uromyces appendiculatus and its potential use for disease resistance screening of Phaseolus vulgaris. Plant Dis. 87:1133-1138.

In June 1989, pycnia and aecia of the bean rust pathogen were observed in eastern Colorado on volunteer plants of pinto bean cvs. UI 114 and UI 126 that grew from seed that remained in the field after harvest the previous season. Harvested aeciospores were viable and produced typical reddish-brown uredinia on unifoliolate leaves of UI 114 seedlings in the greenhouse. Evidence of bean rust overwintering has been confirmed in 10 years from 1989 to 2002 in eastern Colorado and the surrounding region. Overwintering conditions were reproduced at Fort Collins, CO in fall 1992 and spring 1993. Debris treatments had significantly higher disease incidence on stems, total number of lesions on stems, disease incidence on leaves, and total number of lesions on leaves of plants of pinto cvs. UI 114 and Olathe than plants without debris. Bean leaves of both cultivars had significantly higher disease incidence than stems. There also was an increased incidence of aecial infection for UI 114 seedlings that germinated through leaf debris with rust compared with stem debris under greenhouse conditions with abundant moisture. Bean leaf debris smaller than $0.36 \mathrm{~mm}$ in diameter resulted in significantly more aecial lesions on UI 114 than larger leaf debris and stem debris. Additional greenhouse experiments demonstrated that diverse collections of naturally occurring, overwintered, rust-infested bean debris from eastern Colorado produced different levels of pycnial and aecial infection on pinto cvs. UI 114, Olathe, and Chase. Chase, currently resistant to the uredinial stage of the prevalent bean rust races in Colorado and surrounding states, had a low incidence of aecial lesions on seedling stems when exposed to pycnial and aecial stages in the greenhouse. These observations indicate that selection of bean rust resistance genes should rely on multiple sources of resistant germ plasm to counter the potential increase in new races that could derive from sexual recombination in bean-production regions.
\end{abstract}

Additional keywords: ecology, host resistance, pathogenic variability

Uromyces appendiculatus (Pers.:Pers.) Unger, the cause of bean rust, has an autoecious, macrocyclic life cycle that completes all stages on the bean host Phaseolus vulgaris L. After dormancy is broken in favorable environments, overwintered teliospores germinate and produce basidia and basidiospores. Basidiospores infect bean hypocotyls, stems, petioles, and leaves of seedlings, resulting in production of pycnia $(13,14)$ (Fig. 1). Pycnia and aecia were reported to be rare under field conditions in Oregon (17), New York (8), North Dakota (15), and southern Germany (14), but pycnia and aecia were found in 4 of 5 years in Colorado (13) and Nebraska (12) from 1989 to 1993, and 6 of 9 years from 1994 to 2002 (H. F. Schwartz, unpublished data). In Colorado, Nebraska,

Corresponding author: H. F. Schwartz

E-mail: hfspp@lamar.colostate.edu

Accepted for publication 24 April 2003

Publication no. D-2003-0707-02R

(C) 2003 The American Phytopathological Society and North Dakota, pycnia and aecia were observed on volunteer bean plants in winter wheat fields where beans with rust occurred the previous season. In Colorado, pycnia and aecia also were observed on volunteer beans growing in field corn, potato, alfalfa, oat, and fallowed fields in which beans infested with rust were grown during the previous season.

In June 1989, pycnia and aecia of the bean rust pathogen were observed on volunteer plants of pinto bean cvs. UI 114 and UI 126, which were growing from seed missed during bean harvest the previous fall in winter wheat fields. Mature pycnia and aecia were present on adaxial and abaxial surfaces, respectively, of unifoliolate leaves. Pycnia and aecia also were observed on the lower stem and upper hypocotyls of affected plants, apparently where basidiospore infection occurred as seedling leaves and stems emerged through infested bean crop debris (13).

Identification of specific environmental factors and production practices that favor overwintering and sexual recombination would provide insight into host infection by basidiospores and aeciospores. It would also facilitate research on the genetic variability of $U$. appendiculatus.

The objectives of this research were to identify and reproduce cultural conditions favorable for development of the sexual stages of bean rust, and to develop field and greenhouse techniques to facilitate studying the impact of pycnial and aecial stages of $U$. appendiculatus on rust resistance.

\section{MATERIALS AND METHODS}

1992-93 Bay Farm studies. Bean plants (Phaseolus vulgaris) of diverse germ plasm that were heavily infested with a nondifferentiated mixture of rust races provided the initial source of urediniospores for simulated carryover and "outstate" greenhouse studies. Collections were made from naturally infected commercial fields (outstate sources) in eastern Colorado, southwestern Nebraska, northwestern Kansas, and the Colorado State University Bay Farm Research Facility at Fort Collins during 1991 and 1992. Urediniospores were concentrated by vigorously tapping rusted leaves over a $0.355-\mathrm{mm}$ sieve that allowed spores to pass through the sieve but retained contaminating soil and other debris. The spores then were stored at $-4^{\circ} \mathrm{C}$ until needed. Pinto cultivars used for field studies included Olathe (susceptible to many races) and U.I. 114 (susceptible to all races identified from the Central High Plains region (14).

On 4 June 1992 at the Bay Farm, pinto cvs. Olathe and U.I. 114 were sown in adjacent 15.25 -by- $18.25-\mathrm{m}$ areas in $0.76-\mathrm{m}$ wide rows at 185,000 seed/ha. On 23 June, bean seedlings were inoculated with the bulked, dried urediniospores that were stored at $-4^{\circ} \mathrm{C}$. The inoculum was prepared in 20 liters of water with $5 \mathrm{ml}$ of Tween 20 (Roche Applied Science, Indianapolis, IN) to provide a final concentration of $10^{4}$ to $10^{6}$ spores $/ \mathrm{ml}$. Furrow irrigation was applied as needed for bean plant development, and additional overhead sprinkler misting (15 nozzles $\times 3.758$ liters/h) was operated from 20:00 to 21:00 each night to promote rust development. Bean plants from this field were intentionally left standing and, on 28 September 1992, the hard red winter wheat cv. TAM 105 was planted. Wheat was planted directly into the infested bean debris at $67 \mathrm{~kg} / \mathrm{ha}$ within all blocks using a standard grain drill to simulate a no-till or minimum-till wheat rotation following dry bean, which is 
common in eastern Colorado. The wheat field was divided into the following experimental treatments: (i) Olathe pinto bean plus additional bean debris $(15.25$ by $9.1 \mathrm{~m}$ ), (ii) UI 114 pinto bean plus additional bean debris (15.25 by $9.1 \mathrm{~m}$ ), (iii) Olathe pinto bean without additional bean debris ( 15.25 by $9.1 \mathrm{~m}$ ), and (iv) UI 114 pinto bean without additional bean debris (15.25 by $9.1 \mathrm{~m}$ ) (Fig. 2). Additional debris infested with bean rust collected from Colorado, Nebraska, and Kansas was processed using a Vogel stationary thresher to remove seed, and hand broadcast to a 30.5-by-9.1-m area across both cultivars to simulate debris left by combining. Overhead sprinkler misting was applied over each treatment as described previously to simulate irrigated wheat production, and to enhance the sexual stage development of bean rust within the winter wheat canopy. An average of 2.5 to $4.0 \mathrm{~cm}$ of water was applied per month through the sprinkler irrigation system to all treatments to enhance wheat canopy development in fall 1992 and spring 1993. No other management practices were applied to the field study.

On 18 March 1993, samples of fieldconditioned bean debris from Bay Farm
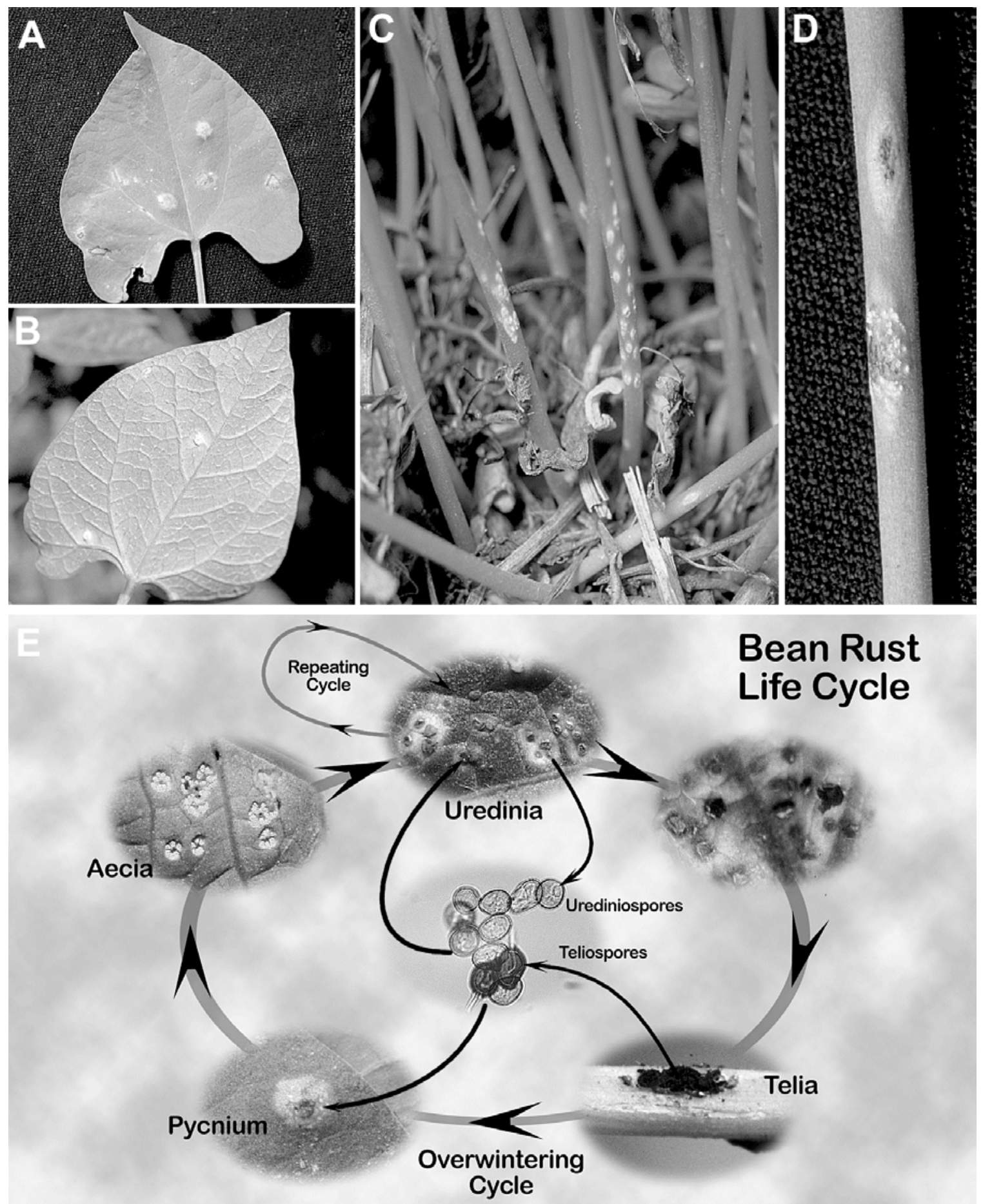

Fig. 1. A and D, Pycnial and B, C, and D, aecial lesion development of Uromyces appendiculatus on leaves and stems of volunteer pinto bean plants following natural exposure to overwintered inoculum in the field, and $\mathbf{E}$, a life cycle diagram of bean rust. 
(approximately $236 \mathrm{~g}$ of U.I. 114 and $160 \mathrm{~g}$ of Olathe dried debris as described below) with rust telia were arbitrarily collected, bulked, and transferred to the greenhouse to check for the occurrence of the sexual stage of $U$. appendiculatus. Also on this date, 20 field locations (replicates) per treatment were arbitrarily selected and marked with flags, and 50 certified seed of Olathe or UI 114 were placed on the soil surface beneath remaining piles of bean debris of treatments with supplemental bean debris (treatments 1 and 2), and on top of barren soil in the treatments without supplemental bean debris (treatments 3 and 4) to simulate seed missed during the previous bean harvest. To provide high humidity and free moisture conditions that are favorable for rust development, bean emergence, and wheat canopy development, the overhead irrigation system was operated as before from 20:00 to 21:00 each night during mid-April to mid-June over the test area. During May and June, as bean seed germinated, emerging bean plants were periodically monitored visually for the presence of rust symptoms or signs (pycnia or aecia). On 24 June 1993, 8 of the 20 replications for each treatment were arbitrarily sampled. Twenty-five bean plants were collected from each replication and taken to the laboratory, and all surfaces of each plant were inspected for signs of pycnia or aecia on leaves or stems. Data were recorded as number of pycnia or aecia per plant, and as incidence of plants with one or more pycnia or aecia.

1993 greenhouse studies. To identify which component of bean debris was most favorable for overwintering and sexual stage conditioning of bean rust teliospores, bean debris was collected from the Bay Farm in March 1993 and separated into four categories: (i) bean stem and petiole debris that was in contact with soil, (ii) large bean leaf debris (did not pass through a $0.85-\mathrm{mm}$ sieve) that was in contact with soil, (iii) medium bean leaf debris (passed through a $0.85-\mathrm{mm}$ sieve but not through a $0.36-\mathrm{mm}$ sieve) that was in contact with soil, and (iv) small bean leaf debris (passed through the $0.36-\mathrm{mm}$ sieve) that was in contact with soil. To obtain uniform-sized bean debris among treatments, each component was ground to a fine material $(<0.36 \mathrm{~mm}$ ) using a Wylie Mill (Arthur H. Thomas Co., Philadelphia). The mill was cleaned thoroughly between grinding of each component.

On 18 March 1993, 16 13-cm-diameter plastic pots each were filled with $70 \mathrm{~g}$ (dry wt) of soil-less potting mix (Terralite; Metromix 200, Milpitas, CA) and compacted to provide a firm planting bed. Each pot was planted with 20 seed of cv. UI 114. Each of the four ground bean debris components was divided into four equal portions, and each portion was spread on top ( 1.5 to $2 \mathrm{~cm}$ deep) of the UI 114 bean seed in each pot. This resulted in four treatments with four replicates each. No additional potting mix was used to cover the seed. A negative control (no debris source) was not used in this experiment because the objective was to compare infection between debris components.

The pots were randomly placed on a greenhouse bench under a plastic tent and $63 \%$ shade cloth, and misted (15 s on, $45 \mathrm{~s}$ off, $24 \mathrm{~h}$ per day) using an automatic overhead misting system (Hardie automatic valves, James Hardie Irrigation, El Paso, TX; short-range cycle timer, Intermatic Inc., Spring Grove, IL; and Rain Bird Brass Fogger nozzles, KBW, Donna, TX) to provide high moisture and humidity. The greenhouse was maintained at $25 \pm 3{ }^{\circ} \mathrm{C}$. On 20 April 1993, each plant was inspected visually for signs of pycnia or aecia on hypocotyls, stems, petioles, and leaves of emerged seedlings.

1994 eastern Colorado survey. Initial studies to verify overwintering of the bean rust fungus involved collection of naturally overwintered debris plus conditioned telia from bean-growing regions where rust outbreaks occurred during the 1993 growing season. Debris was collected from three locations: (i) Agricultural Research Demonstration and Education Center (ARDEC) at Fort Collins, Colorado State University, from pinto cv. UI 114, collected 23 May 1994; (ii) Burlington, CO (approximately $550 \mathrm{~km}$ southeast of Fort Collins), a mixture from susceptible pinto cv. Othello $(19.3 \mathrm{~km}$ south and $8 \mathrm{~km}$ east of town), collected 25 May 1994, and miscellaneous cultivars (susceptible to resistant) in the 1993 Colorado State University crops testing variety trial experiment (14.5 km south and $8 \mathrm{~km}$ east), collected 25 May 1994; and (iii) Yuma, CO (approximately $400 \mathrm{~km}$ southeast of Fort Collins), from pinto cv. Bill Z $(24 \mathrm{~km}$ north and $1.6 \mathrm{~km}$ east of town), collected 25 May 1994. Enough soil (upper 5-cm profile) to fill two 19-liter buckets and bean debris to fill two 150-liter plastic trash bags were collected from up to 20 randomly selected sites at each location. All collected debris was ground using a Wylie Mill to pass through a $<0.36-\mathrm{mm}$

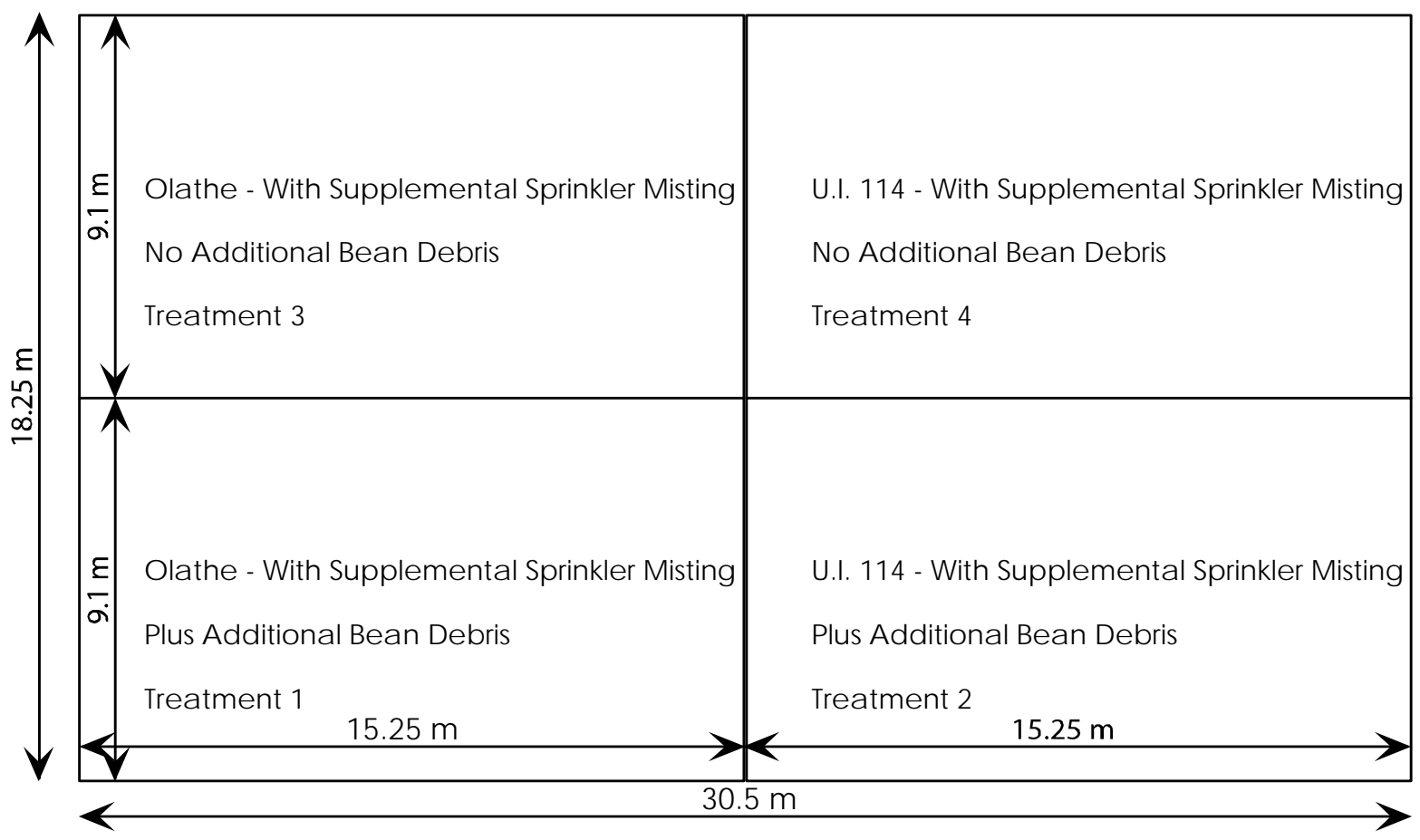

Fig. 2. Field plot design at Colorado State University Bay Farm Research Facility at Fort Collins during 1991 and 1992. 
sieve. The mill and sieve were cleaned thoroughly between treatments.

To simulate bean seed germination through bean debris, 45 rectangular plastic flats (American Clay Works, Denver), 27 $\mathrm{cm}$ long by $13.5 \mathrm{~cm}$ wide by $12.5 \mathrm{~cm}$ deep, were filled with $280 \mathrm{~g}$ (dry wt) of soil-less potting mix and compacted to form a firm seeding bed. Fifteen flats each of the pinto cvs. Chase, Olathe, and UI 114 were planted with 30 seed (15 seed/row, 2 rows/flat). The seed of each flat were covered with $62 \mathrm{~g}$ (dry wt) of soil-less potting mix, followed by $22 \mathrm{~g}$ of field soil, and $22 \mathrm{~g}$ of debris from one of the three debris sources in three successive layers. Each layer was approximately 0.5 to $1 \mathrm{~cm}$ thick. This resulted in nine treatments (three cultivars by three sources of debris), and each treatment was replicated five times. Flats then were randomly placed under plastic tents and shade cloth on greenhouse benches and misted for 30 days as previously described. The greenhouse was maintained at $25 \pm 3^{\circ} \mathrm{C}$ with diffuse light. Pycnial and aecial counts were made on 2 July.

Statistics. Statistical analyses of pycnial and aecial counts were conducted with the GLM procedure and Student-NewmanKeuls (SNK) mean separation test $(\alpha=$ 0.05) using SAS System Software (SAS Institute Inc., Cary, NC), and one-way analysis of variance (ANOVA-1), and SNK $(\alpha=0.05)$ using MSTAT (Michigan State University, East Lansing).

\section{RESULTS}

1992-93 Bay Farm study. Pycnia and aecia were found on seeded plants in all

Table 1. Incidence of infected plants and mean number of aecial clusters of Uromyces appendiculatus on stems and leaves of pinto cvs. UI 114 and Olathe that emerged in the absence or presence of 1992 field-conditioned bean debris during 1993 at the Bay Farm in Fort Collins, CO $^{z}$

\begin{tabular}{lccccc}
\hline & \multicolumn{2}{c}{ Aecial clusters on stems } & & \multicolumn{2}{c}{ Aecial clusters on leaves } \\
\cline { 2 - 3 } \cline { 5 - 6 } Treatment & Incidence (\%) & Mean & & Incidence (\%) & Mean \\
\hline UI 114 with debris & 64.0 & 2.01 & & 47.0 & 4.08 \\
UI 114 without debris & 3.5 & 0.06 & & 11.0 & 0.36 \\
Olathe with debris & 52.5 & 2.38 & & 70.5 & 4.46 \\
Olathe without debris & 2.5 & 0.07 & & 8.5 & 0.11 \\
\hline
\end{tabular}

${ }^{\mathrm{z}}$ Mean of eight replicates, 25 plants each. Stems include stems and hypocotyls; leaves include leaves and leaf petioles; Mean $=$ mean per plant.

Table 2. Effect of sources of variation on the mean number of Uromyces appendiculatus aecial clusters on leaves and stems of cvs. Olathe and UI 114 seedlings which germinated in the presence or absence of rust infested bean debris

\begin{tabular}{|c|c|c|c|c|c|}
\hline \multirow[b]{2}{*}{ Test } & \multicolumn{3}{|c|}{ Source of variation } & \multirow[b]{2}{*}{$\operatorname{Mean}^{z}$} & \multirow[b]{2}{*}{$P>0.05$} \\
\hline & Cultivar & Debris $^{x}$ & Component $^{\mathrm{y}}$ & & \\
\hline \multirow[t]{2}{*}{1} & Olathe & $\ldots$ & $\ldots$ & $1.75 \mathrm{a}$ & 0.5507 \\
\hline & UI 114 & $\ldots$ & $\ldots$ & $1.62 \mathrm{a}$ & $\ldots$ \\
\hline \multirow[t]{2}{*}{2} & $\ldots$ & Debris & $\ldots$ & $3.23 \mathrm{a}$ & $<0.0001$ \\
\hline & $\ldots$ & No debris & 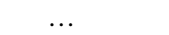 & $0.15 \mathrm{~b}$ & \\
\hline \multirow[t]{2}{*}{3} & $\ldots$ & $\ldots$ & Leaves & $2.25 \mathrm{a}$ & $<0.0001$ \\
\hline & $\ldots$ & $\ldots$ & Stems & $1.12 \mathrm{~b}$ & \\
\hline \multirow[t]{4}{*}{4} & $\ldots$ & Debris & Leaves & $4.27 \mathrm{a}$ & $<0.0001$ \\
\hline & $\ldots$ & Debris & Stems & $2.19 \mathrm{~b}$ & $\ldots$ \\
\hline & $\ldots$ & No debris & Leaves & $0.23 \mathrm{c}$ & $\ldots$ \\
\hline & $\ldots$ & No debris & Stems & $0.07 \mathrm{c}$ & \\
\hline \multirow[t]{4}{*}{5} & Olathe & Debris & $\ldots$ & $3.42 \mathrm{a}$ & 0.2517 \\
\hline & Olathe & No debris & $\ldots$ & $0.09 \mathrm{a}$ & $\ldots$ \\
\hline & UI 114 & Debris & $\ldots$ & $3.04 \mathrm{a}$ & $\ldots$ \\
\hline & UI 114 & No debris & $\ldots$ & $0.21 \mathrm{a}$ & $\ldots$ \\
\hline \multirow[t]{4}{*}{6} & Olathe & $\ldots$ & Leaves & $2.28 \mathrm{a}$ & 0.7699 \\
\hline & Olathe & $\ldots$ & Stems & $1.22 \mathrm{a}$ & $\ldots$ \\
\hline & UI 114 & $\ldots$ & Leaves & $2.22 \mathrm{a}$ & $\ldots$ \\
\hline & UI 114 & $\ldots$ & Stems & $1.03 \mathrm{a}$ & $\ldots$ \\
\hline \multirow[t]{8}{*}{7} & Olathe & Debris & Leaves & $4.46 \mathrm{a}$ & 0.7610 \\
\hline & Olathe & Debris & Stems & $2.38 \mathrm{a}$ & $\ldots$ \\
\hline & Olathe & No debris & Leaves & $0.11 \mathrm{a}$ & $\ldots$ \\
\hline & Olathe & No debris & Stems & $0.07 \mathrm{a}$ & $\ldots$ \\
\hline & UI 114 & Debris & Leaves & $4.08 \mathrm{a}$ & $\ldots$ \\
\hline & UI 114 & Debris & Stems & $2.01 \mathrm{a}$ & $\ldots$ \\
\hline & UI 114 & No debris & Leaves & $0.36 \mathrm{a}$ & $\ldots$ \\
\hline & UI 114 & No debris & Stems & $0.06 \mathrm{a}$ & $\ldots$ \\
\hline
\end{tabular}

$\bar{x}$ Bean rust-infested debris from Colorado, Nebraska, and Kansas was processed using a Vogel stationary thresher to remove seed, and hand broadcast to simulate debris left by combining.

y Aecial lesions found on leaves and leaf petioles were classified as leaf lesions, while hypocotyl and stem lesions were classified as stem lesions.

${ }^{\mathrm{z}}$ Means followed by the same letter are not significantly different according to Student-NewmanKeuls test $(P=0.05$, error degrees of freedom $=1,585$, error mean square $=18.25859)$.

treatments by 14 June 1993 at the Bay Farm site. Small, young, snow-white, aecia 2 to $4 \mathrm{~mm}$ in diameter were found on the hypocotyls, stems, petioles, and adaxial and abaxial leaf surfaces of seedlings of Olathe and UI 114. White to light-yellow to light-brown pycnia, measuring up to 6 $\mathrm{mm}$ in diameter, were also abundant on volunteer and bean seedlings beneath the winter wheat canopy. Both pycnia and aecia were found on volunteer and seeded plants that germinated through bean debris piles and on top of barren soil surfaces. Aecial clusters or lesions were obvious with one or more aecial cups or horns. Aecial cups appeared as fragile, papery cylinders, with numerous hyaline aeciospores filling the interior, and spilling onto the surrounding aecia and plant surfaces when observed at $\times 10$ to $\times 25$. As aecial cups aged, they became creamy white to yellow-tan and often broke away from the aecium, leaving a nondescript brownishtan necrotic remnant or lesion on the plant. Because of the difficulty of separating apparently old aecial remnants from other necrotic lesions, only aecia with visible cups were counted, which may have underestimated the actual number of aecia. Aecial lesions found on leaves and leaf petioles were classified as leaf lesions, while hypocotyl and stem lesions were classified as stem lesions.

Bean seedlings, which germinated through piles of bean debris, had the greatest number of lesions per plant on both stems and leaves (Table 1). Mean number of aecial clusters on plants ranged from $<1$ to 4.4 .

The GLM procedure was used to identify the sources of variation in the experiment (Table 2). Cultivars did not affect disease incidence, but seedlings that germinated through debris had more aecial clusters than no debris, and leaves had more clusters than stems $(P<0.0001)$. Across both cultivars, there was a significantly $(P<0.0001)$ higher incidence of lesions on bean leaf than stem components when seedlings germinated through bean debris, but lesions on stems and leaves were not significantly different for bean seedlings that did not germinate through bean cover. None of the other interactions had an effect on the number of aecial clusters.

1993 greenhouse study. UI 114 bean seedlings that germinated through ground bean stem debris, leaf debris larger than $0.85 \mathrm{~mm}$, leaf debris between 0.36 and $0.85 \mathrm{~mm}$, and leaf debris smaller than $0.36 \mathrm{~mm}$ had $23,18,17$, and $60 \%$ of the plants with aecia, respectively. Plants treated with ground bean debris treatment smaller than $0.36 \mathrm{~mm}$ had significantly more aecial lesions than all other treatments.

1994 eastern Colorado survey. The results of the 1994 greenhouse study, which compared three sources of bean debris, are 
presented in Table 3. The location-cultivar interaction was not significant; therefore, each factor was analyzed separately. Debris from the Yuma location produced significantly $(P<0.05)$ higher numbers of aecial lesions than debris samples from ARDEC or Burlington. Pinto cv. Olathe had significantly more aecial lesions than cv. Chase, whereas cv. UI 114 was not significantly different from either cultivar.

\section{DISCUSSION}

Overwintering of $U$. appendiculatus has been mentioned only briefly in the literature. Although several dry bean researchers, including C. F. Andrus (1) and W. J. Zaumeyer (16), have mentioned the sexual stage during discussions on bean rust biology and management, almost all references indicate that this is a rare occurrence. Schwartz et al. (13) reported the first evidence of the bean rust pathogen overwintering as teliospores that formed sexual stages in Colorado in a winter wheat field planted into bean straw using minimum tillage. Evidence of overwintering (sexual stages) has now been found during 10 of the last 14 years from 1989 to 2002 in eastern Colorado and the surrounding region. We have not found any evidence of urediniospore overwintering in Colorado as reported in North Dakota (5); however, additional monitoring and surveying is warranted to determine if this stage can contribute to early-season outbreaks of rust on the semi-arid high plains.

The high incidence of pycnia and aecia on the lower stem of infected bean plants was observed repeatedly in field surveys (13) and greenhouse studies. Comparisons of rusted leaf and stem components revealed that small leaf tissue (less than 0.36 $\mathrm{mm}$ ) was associated with increased aecial incidence, presumably due to a greater concentration of conditioned teliospores per unit of debris. Larger-sized leaf components, stem debris, and pod debris (results not reported) were generally associated with a lower incidence of aecia. This suggests that collection of conditioned teliospores from natural or artificial settings must effectively recover small pieces of rusted plant debris, and probably even surface soil which may contain conditioned teliospores released from decomposing plant debris. Integrated pest management and bean rust pathology personnel must carefully evaluate the contribution of infected plant parts such as stems and leaves, as well as the whole plant, to the disease cycle and development.

Potential causes for the increase in observations of the sexual stage include weather patterns that are more favorable for development; monoculture cropping and increased crop acreage that have enhanced the potential for infection; minimum tillage operations that do not incorporate previously infected crop debris; varietal selection in the absence of overwintering stages that may result in cultivars more susceptible to sexual spore stages; a shift in the pathogen population to a race or group of races that utilize the sexual cycle more commonly; or improved and more timely scouting techniques. Regardless of the reason that the sexual stage was not previously reported, increased awareness now may provide clues to more timely and effective management of bean rust in the high plains of Colorado and surrounding states.

Management of bean rust through the use of cultural practices, primarily crop rotation and sanitation, has been reported for many years $(2,10,13,16)$. Deep tillage, crop rotation of 2 to 4 years out of bean, elimination of bean debris, elimination of volunteer bean plants, and proper adjustment of threshing equipment to reduce seed loss decrease carryover of the pathogen and its ability to bridge between old and new bean fields within a production region. These cultural practices also reduce the potential for overwintering of urediniospores as primary inoculum (5).

Occurrence of the sexual stage at the Bay Farm during 1993 provided an opportunity to study cultural conditions that favor overwintering and completion of the sexual stage. During this study, evidence of early-season asexual stages (uredinia) that could have resulted from overwintered urediniospores, as observed in North Dakota (5), were not observed. In this field study, in the presence of adequate water, there was a higher incidence of aecial clusters on bean seedlings that germinated through telia-infested debris. This apparently is due to the increased inoculum level or more favorable microclimatic conditions, presumably higher moisture, that occur within the debris piles. These results agree with the research of Gold and Mendgen (4), Groth and Mogen (7), and Venette et al. (15), indicating that high moisture and free water favor basidiospore germination and infection.

There was a low incidence of aecial clusters on volunteer bean seedlings that did not germinate through bean debris piles. In this case, teliospores could have overwintered in the soil, then produced basidiospores surrounding the emerging volunteer bean seedling, or basidiospores could have been windblown from nearby bean cull piles. In either case, deep incorporation of soil or bean debris of rustinfested residue from the previous growing season will reduce or eliminate the potential for overwintering and initiation of the sexual stage and asexual stage (5) of the bean rust pathogen the following season or crop cycle and, therefore, reduce initial inoculum and delay infection of new crop plants.

The 1993 and 1994 greenhouse studies verified that germinating bean seed in high-moisture conditions through overwintered, rusted bean debris was an effective and repeatable method to induce fungal sexual stages. Aecial development in the absence of insects suggests that cross fertilization between pycnia occurred via other means, such as moisture and, possibly, physical proximity of adjacent pycnia that developed on infected tissues. Leaf debris, especially smaller components, caused greater infection than stem debris.

Kolmer et al. (9) report that both basidiospore and urediniospore stages of rust resistance are governed by the same gene or group of fungal genes, and McCallum et al. (11) reported that a single gene governed teliospore production. If this is the case, then the low incidence of aecial infections on cv. Chase in the 1994 greenhouse study is particularly alarming. Chase, a cultivar that is currently considered resistant to the prevalent races of rust in Colorado, Kansas, and Nebraska, became available in 1995 for commercial production in this region. Chase has the rust resistance gene designated $U r 3$, which has been incorporated into germ plasm and released cultivars of many bean-breeding programs nationally. Incorporation of this gene as a major dominant source of resistance could shorten the life span for the $U r-3$ gene unless other techniques are developed to prolong its usefulness. The availability of cultivars of some market classes, such as pinto, that are both locally adapted and resistant to the current rust races are limited. Many of those that are resistant are not widely accepted because of agronomic deficiencies, including poor seed quality and late maturity.

With the occurrence of the sexual stage there is a potential increase in the number of new rust races derived as a result of sexual recombination (6). If the majority of resistant cultivars employ single dominant or similar gene resistances and there is sexual recombination in the pathogen population, then the potential for the emergence of a compatible and new rust race or races is enhanced. Bean rust resistance

Table 3. Percentage of pinto cvs. UI 114, Olathe, and Chase that developed Uromyces appendiculatus aecial clusters following exposure to different sources of 1993 field-conditioned bean debris

\begin{tabular}{lc}
\hline Treatments & ${\text { Incidence }(\boldsymbol{\%})^{\mathbf{z}}}$ \\
\hline Cultivar & \\
UI 114 & $1.4 \mathrm{ab}$ \\
Olathe & $1.8 \mathrm{a}$ \\
Chase & $0.9 \mathrm{~b}$ \\
Location & \\
ARDEC & $1.0 \mathrm{~b}$ \\
Burlington & $1.1 \mathrm{~b}$ \\
Yuma & $2.0 \mathrm{a}$ \\
\hline
\end{tabular}

${ }^{\mathrm{z}}$ Mean of five replications (25 plants per replication); one-way analysis of variance comparison; means within a column followed by the same letter are not significantly different according to Student-Newman-Keuls test $(P<0.05)$, coefficient of variance $=66.2$. 
genes deployed in this scenario would have a more limited usefulness. Plant breeders and integrated pest management personnel may be required to screen germ plasm against a wider array of races, promote more complicated genetic rotations, plant pyramids or mixtures, and use protectant and systemic fungicides to manage bean rust $(3,14)$.

\section{ACKNOWLEDGMENTS}

Research support was provided by the Colorado State University Agricultural Experiment Station, Colorado Dry Bean Administrative Committee, Nebraska Dry Bean Commission, and Colorado Bean Network.

\section{LITERATURE CITED}

1. Andrus, C. F. 1931. The mechanism of sex in Uromyces appendiculatus and $U$. vignae. $\mathrm{J}$. Agric. Res. 42:559-587.

2. Brandon, J. F., Robertson, D. W., Binkley, A. M., and Kreutzer, W. A. 1943. Field bean production without irrigation in Colorado. Colo. Agric. Exp. Stn. Bull. 482:17-18.

3. Brick, M. A., and Grafton, K. F. 1999. Improvement of medium-seeded Durango cultivars. Pages 223-253 in: Common Bean Im- provement in the Twenty-first Century. S. P. Singh, ed.. Kluwer Academic Publishers, Norwell, MA.

4. Gold, R. E., and Mendgen, K. 1984. Cytology of basidiospore germination, penetration, and early colonization of Phaseolus vulgaris by Uromyces appendiculatus var. appendiculatus. Can J. Bot. 62:1989-2002.

5. Gross, P. L., and Venette, J. R. 2001. Overwinter survival of bean rust urediniospores in North Dakota. Plant Dis. 85:226-227.

6. Groth, J. V., McCain, J. W., and Roelfs, A. P. 1995. Virulence and isozyme diversity of sexual versus asexual collections of Uromyces appendiculatus (bean rust fungus). Heredity 75:234-242.

7. Groth, J. V., and Mogen, B. D. 1978. Completing the life cycle of Uromyces phaseoli var. typica on bean plants. Phytopathology 68:1674-1677.

8. Jones, E. D. 1960. Aecial stage of bean rust found in New York state. Plant Dis. Rep. 44(10):809.

9. Kolmer, J. A., Christ, B. J., and Groth, J. V. 1984. Comparative virulence of monokaryotic and dikaryotic stages of five isolates of Uromyces appendiculatus. Phytopathology 74:111-113.

10. Leach, J. G. 1923. Colorado plant diseases. Colo. Agric. Exp. Stn. Bull. 259:40.
11. McCallum, B. D., Groth, J. V., and Roelfs, A. P. 1997. Mendelian inheritance of teliospore production in Uromyces appendiculatus. Mycologia 89:551-557.

12. Schwartz, H. F., McMillan, M. S., and Lancaster, G. K. 1994. Volunteer beans with rust and white mold inocula in winter wheat. Plant Dis. 78:1216.

13. Schwartz, H. F., McMillan, M. S., and Vaughn, M. R. 1989. Aecial and pycnial stages of bean rust in Colorado. Plant Dis. 74:80.

14. Stavely, J. R., and Pastor-Corrales, M. 1989. Rust. Pages 159-194 in: Bean Production Problems in the Tropics. H. F. Schwartz and M. Pastor-Corrales, eds. International Center for Tropical Agriculture, Cali, Colombia.

15. Venette, J. R., Olson, B. M., and Nayes, J. B. 1978. Bean rust pycnia and aecia in North Dakota. Annu. Rep. Bean Improv. Coop. 21:49.

16. Zaumeyer, W. J. 1946. Saving beans from rust. USDA-ARS. Bureau of Plant Industry, Soils, and Agricultural Engineering, Division of Fruit and Vegetable Crops and Diseases. USDA, Washington, DC.

17. Zaumeyer, W. J., and Thomas, H. R. 1957. Rust. A monographic study of bean diseases and methods for control. Rev. Ed. Tech. Bull. No. 868. USDA, Washington, DC. 